УДК 625.144.5/7(043)

\title{
НАПРЯМИ МОДЕРНІЗАЦІЇ ВІБРАЦІЙНИХ ГРОХОТІВ ЩЕБЕНЕОЧИЩУВАЛЬНИХ МАШИН
}

\author{
К-ти техн. наук Л. М. Козар, Г. М. Афанасов, магістрант О. С. Харківський \\ НАПРАВЛЕНИЯ МОДЕРНИЗАЦИИ ВИБРАЦИОННЫХ ГРОХОТОВ \\ ЩЕБНЕОЧИСТИТЕЛЬНЫХ МАШИН
}

К-ты техн. наук Л. М. Козарь, Г. М. Афанасов, магистрант А. С. Харьковский

AYS OF MODERNISATION OF RIDDLERS FOR BALLAST CLEANERS

Cand. of techn. sciences. L. Kozar, H. Afanasov, master student O. Kharkivskyi

Приведены результаты информационного поиска в направлении совершенствования конструкиий вибрациионных грохотов щебнеочистительных машин. Найдены существующие технические решения, которые направлены на повышение производительности этих устройств, надежности, долговечности их узлов, снижение металло- и энергоемкости, улучшение условий труда обслуживающего персонала.

Определено основное перспективное направление модернизации вибрачионных грохотов - применение резонирующих лент-струн вместо плетеных металлических проволочных сит.

Ключевые слова: железнодорожный путь, щебеночный балласт, глубокая очистка, щебнеочистительная машина, вибрационный грохот, лента-струна.

Наведено результати інформаційного пошуку в напрямку вдосконалювання конструкцій вібраційних грохотів щеебенеочисних машин. Знайдено існуючі технічні рішення, які направлені на підвищення продуктивності ичих пристроїв, надійності, довговічності їхніх вузлів, зниження метало- та енергоємності, поліпшення умов праці обслуговуючого персоналу.

Визначено основний перспективний напрямок модернізачії вібрачійних грохотів застосування резонуючих стрічок-струн замість плетених металевих дротових сит.

Ключові слова: залізнична колія, щебеневий баласт, глибоке очищення, щуебенеочисна машина, вібраиійний грохот, стрічка-струна.

Modern operating conditions of Ukrainian railways require to introduce alternative technologies of repair and routine maintenance of trunk railways. One of such technologies is the deep cleaning of crushed-stone ballast bed (from 400 to $700 \mathrm{~mm}$ ) without lifting of railway track.

A research aim is to improve efficiency and quality of the deep cleaning of crushed-stone ballast bed.

The literature and patent search in the way of constructional upgrading of riddlers for ballast cleaners is complete. Authors found necessary legacy engineering solutions. These concepts allow to improve the capacity of devices, dependability, productive life of their components, lower the steel and energy intensity, improve the working conditions of operating personnel.

Basic perspective way of improvement of riddlers is application of resonant belts-strings instead of the wattled metallic wire screens.

The got results are basis for further researches.

Keywords: railway track, crushed-stone ballast, deep cleaning, ballast cleaner, riddler, beltstring.

Вступ. Сучасні умови експлуатації залізниць України вимагають впровадження 
на магістральних лініях ресурсозберігаючих технологій ремонту i утримання колії. Однією 3 таких технологій $\epsilon$ глибоке очищенню баластового шару щебеню без піднімання колії.

Глибоким називають очищення баласту на глибину більше 200 мм (зазвичай від 400 до 700 мм). Таке очищення здійснюється спеціальними високопродуктивними машинами, зокрема машинами типу СЧ-1000, RM-80 українського виробництва. В якості основного очисного пристрою у цих машинах використовуються плоскі вібраційні грохоти (спеціальні сита).

Існує низка факторів, які негативно впливають на ефективність i якість глибокого очищення щебеневих баластів, тому визначення напрямків удосконалення конструкцій робочих органів згаданих вище машин $\epsilon$ актуально науковою задачею.

Постановка проблеми у загальному вигляді та іiі зв'язок із важливими науковими та практичними завданнями. Досвід експлуатації машин для глибокого очищення баласту показав, що вузлом, який визначає ефективність їх роботи, $\epsilon$ щебенеочисний пристрій. Отже розв'язати задачі підвищення ефективності експлуатації машин розглядуваного типу та якості ремонту колії в першу чергу можна шляхом наукових досліджень, спрямованих на удосконалення конструкції очисного пристрою - плоского вібраційного грохота.

Аналіз останніх досліджень i публікацій. Проблемі дослідження процесу грохочення сипких і кускових матеріалів на вібраційних грохотах присвячена велика кількість робіт, найбільший вклад у створення теоретичних основ яких внесли I.I. Блехман [1], Л.А. Вайсберг [2], І.Ф. Гончаревич [3] та ін.

Процес очищення баластів залізничної колії досліджений у роботах В.Ю. Гапеєнко і С.О. Самохіна. Зокрема подані результати аналізу технологічних прийомів для підвищення якості глибокого очищення вологих баластів за рахунок застосування технічних засобів, що $\epsilon$ в наявності [4]. Рекомендовані раціональні конструктивні параметри плоских грохотів - кількість ярусів сит, розміри чарунок, кути нахилу, площа поверхні просівання, виконана градація грохотів за продуктивністю [5].

Визначені основні компоненти процесу очищення щебеневого баласту методом системного аналізу: «вібраційний грохот», «баласт», «подача баласту на грохот», установлені причинно-наслідкові зв'язки між елементами та їх взаємний вплив [6].

Результати аналізу останніх досліджень підтвердили, що глибоке очищення баласту на сьогодні залишається однією з базових ресурсозберігаючих

технологій колійного господарства, але існує низка невирішених проблем щодо ефективності роботи очищувальних пристроїв - вібраційних грохотів, зокрема поверхонь просівання.

Визначення мети та задачі дослідження. Метою $є$ підвищення ефективності та якості глибокого очищення баласту залізничної колії. Для досягнення поставленої мети на першому етапі досліджень треба здійснити інформаційний пошук, за результатами якого визначити напрями удосконалення очисних пристроїв (вібраційних грохотів) колійних машин.

Основна частина дослідження. Поверхні просівання грохотів повинні задовольняти дві найважливіші вимоги забезпечувати високу ефективність грохочення із заданою крупністю та мати максимально можливий термін служби. У наш час на грохотах щебенеочисних машин застосовуються плетені металеві дротові сита, недоліком яких $\epsilon$ «замазування» їx липким засмічувачем під час роботи на вологих баластах. Це приводить до зменшення живого перерізу поверхні просівання та, як наслідок, зниження продуктивності та якості очищення баласту. У гірничій промисловості на дробильно-сортувальних комплексах застосовуються грохоти з гумовострунними стрічковими ситами [7] (рис. 1).

Maca i жорсткість струн у ситах підібрані таким чином, що під дією віброзбудника за рахунок резонансу вони здійснюють коливання 3 амплітудою, яка на 
величину від 5 до 6 разів перевищує амплітуду коливань грохота. Вільно укладена поліамідна класифікувальна сітка на підтримному ситі сприймає коливання резонуючих гумовострунних стрічок i за рахунок цього інтенсифікується процес грохочення. Така конструкція відрізняється низькою металоємністю i потужністю приводу у порівнянні 3 традиційними металевими ситами.

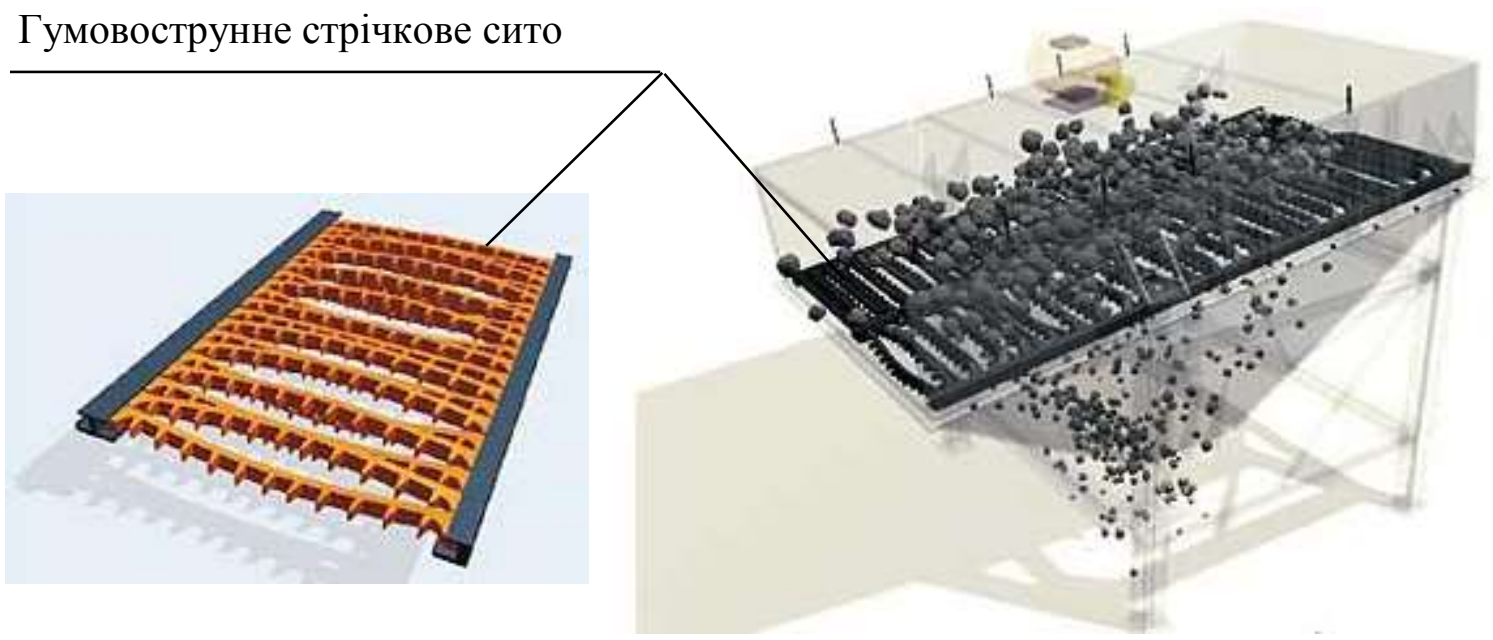

Рисунок 1 - Віброгохот з резонуючим гумовострунним стрічковим ситом

Існує позитивний досвід застосування резонуючих стрічково-струнних сит у віброгрохоті колійної баластоочищувальної машини $\mathrm{RM}-80 . \quad$ Експлуатаційні випробування підтвердили, що таке технічне рішення $\epsilon$ перспективним напрямом у підвищенні якості очищення вологих i липких щебеневих баластів [6]. Термін служби поверхні просівання подовжується більш ніж у 2 рази у порівнянні 3 металевими ситами.

Викликає зацікавленість конструкція грохота для сортування баласту залізничної колії [8] (рис. 2), який містить верхнє металеве сито і нижнє сито, виконане у вигляді окремих фрагментів 3 набраними в них еластичними стрічками-струнами, установленими 3 можливістю коливань із амплітудою, яка від 1,5 до 2 разів перевищує амплітуду коливань верхнього сита. Фрагменти розташовані каскадно 3 кутом нахилу до горизонту, меншим на величину від 4 до $10^{\circ}$ кута нахилу верхнього металевого сита. Це підвищує ефективність просівання вологих і засмічених баластів залізничної колії.

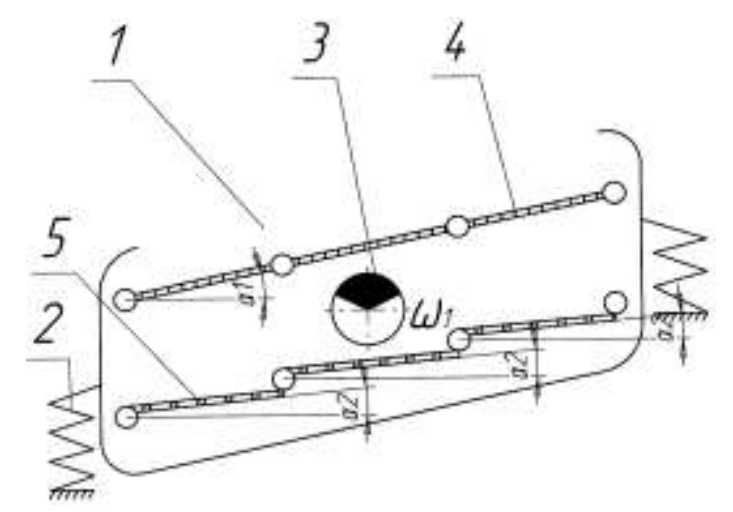

Рисунок - 2 Грохот для сортування баласту залізничної колії [8]:

1 - короб; 2 - пружні амортизатори; 3 - вібропривід;

4 - верхнє металеве сито; 5 - нижнє сито

Існує рішення щодо використання одної, випадковим чином, групами, у кожній стрічок-струн, які мають різні власні частоти 3 яких середнє значення власної частоти коливань і установлені під кутом одна до коливань змінюється від групи до групи від 
максимального на завантаженні до мінімального на розвантаженні. У результаті збільшується інтенсивність розпушення i сегрегації матеріалу, що знаходиться на грохоті, i, як наслідок, підвищується ефективність розділення [9].

Одним iз можливих шляхів підвищення ефективності просівання, продуктивності грохота та зниження енерговитрат $\epsilon$ забезпечення гвинтової траєкторії руху часток матеріалу у бік розвантажувального вікна за рахунок одночасного накладення кругових коливань поперек жолобів і прямолінійних коливань уздовж жолобів поверхні просівання [10].

Забезпечити оптимальні режими просівання у залежності від якості, стану баласту та завантаження грохота пропонується шляхом його оснащення системою автоматичного керування 3 датчиками контролю амплітуди i частоти коливань. При цьому підвіска передбачає можливість регулювання жорсткості у вертикальній i горизонтальній площинах, а віброзбудник може змінювати частоту коливань [11]. Позитивний ефект також можна отримати за рахунок регулювання траєкторій коливань поверхні просівання [12].

Підвищити надійність грохота можна, встановивши над ситом захисний пристрій у вигляді пакету ланцюгів, з’єднаних 3 коробом, на який подається матеріал для просівання [13].
Слід приділяти увагу підвищенню експлуатаційних якостей грохотів. Існують рішення щодо оснащення підшипникових вузлів віброзбудника додатковими ємностями запатентованої конструкції [14] для збільшення терміну експлуатації та покращення умови праці обслуговуючого персоналу, а також розташування віброзбудника на периферії боковин у вирізах, які мають форму півкола [15], 3 метою підвищення ремонтопридатності грохота.

\section{Висновки 3 дослідження i перспективи, подальший розвиток у} даному напрямку. За результатами інформаційного пошуку визначені існуючі технічні рішення щодо удосконалення конструкцій вібраційних грохотів баластоочищувальних машин, які направлені на підвищення продуктивності цих пристроїв, надійності, терміну експлуатації їхніх вузлів, знизження метало- та енергоємності, покращення умов праці обслуговуючого персоналу.

Основним перспективним напрямом модернізації вібраційних грохотів $\epsilon$ застосування резонуючих гумовострунних стрічкових сит замість плетених металевих дротових сит.

Отримані результати є підгрунтям для подальших досліджень 3 підвищення ефективності та якості глибокого очищення баласту залізничної колії.

\section{Список використаних джерел}

1. Производительность вибрационных грохотов с активными рабочими поверхностями [Текст] / И. И. Блехман, О. А. Вяльцева, Л. А. Вайсберг, А. Я. Фидлин // Исследования процессов, машин и аппаратов разделения материалов по крупности : межведомств. сб. науч. тр. - Л. : Механобр, 1988. - С. 20-35.

2. Вайсберг Л. А. Проектирование и расчет вибрационных грохотов [Текст] / Л. А. Вайсберг. - М. : Недра, 1986. - 144 с.

3. Гончаревич И. Ф. Теория вибрационной техники и технологии [Текст] / И. Ф. Гончаревич, К. В. Фролов. - М. : Наука, 1981. - 320 с.

4. Гапеенко Ю. В. Очистка щебня повышенной влажности [Текст] / Ю. В. Гапеенко, С. А. Самохин, Р. Р. Кадыров // Путь и путевое хозяйство. -2000. - № 9. - С. 18 21.

5. Гапеенко Ю. В. Плоские вибрационные грохоты на щебнеочистителях [Текст] / Ю. В. Гапеенко, С. А. Самохин // Путь и путевое хозяйство. - 1999. - № 10. - С. 14-17.

6. Краснов О. Г. Повышение эффективности глубокой очистки балласта железнодорожного пути совершенствованием щебенеочистительных устройств [Текст] : дис. 
... канд. техн. наук : 05.22.06, 05.05.04 / Краснов Олег Геннадьевич. - СПб. , 2002. - 160 с. Библиогр. : с. 126-136.

7. Дробильно-сортировочный комплекс [Электронный ресурс] : разработка и продажа горного оборудования / Горная компания «Логвинов и Партнеры». - Режим доступа : http://loginov.com.ua. - (Дата обращения: 26.02.2015).

8. Пат. 2275252 Российская Федерация, МПК ${ }^{7}$ В 07 В 1/46. Грохот для сортировки балласта железнодорожного пути [Текст] / Краснов О. Г., Кириков А. К. ; патентообладатель Всерос. науч.-исслед. и конструктор.- технолог. ин-т подвижного состава. - № 2000131736/09 ; заявл. 15.09.04 ; опубл. 27.04.06. - 3 с.

9. Пат. 69225 Україна, МПК В 07 В 1/40. Грохот вібраційний [Текст]/ В. П. Надутий, Є. С. Лапшин, О. І. Шевченко; заявник і патентовласник Ін-т геотехн. механіки ім. М.С. Полякова Нац. академ. наук України. - U 2011 11345; заявл. 26.09.11 ; опубл. 25.04.12, Бюл. № 8. -3 с.

10. Пат. 81082 Україна, МПК В 07 В 1/46. Вібраційний грохот [Текст] / В. П Франчук, В. О. Федоскін, В. Ф. Куниця ; заявник і патентовласник держ. вищ. навч. заклад «Нац. гірничий ун-т». - u 201213153 ; заявл. 19.11.12 ; опубл. 25.06.13, Бюл. № 12. - 3 с.

11. Пат. 2394654 Российская Федерация, МПК В 07 В 1/40, В 07 В 1/42. Грохот вибрационный [Текст] / Бидуля А. Л., Кириков А. К., Краснов О. Г., Воробьев С. А. ; патентообладатель ОАО РЖД. - № 2009119199/03 ; заявл. 21.05.09 ; опубл. 20.07.10. - 3 с.

12. Пат. 77403 Україна, МПК В 07 В 1/40. Вібраційний грохот [Текст]/ В. П. Надутий, П. В. Левченко ; заявник і патентовласник Ін-т геотехн. механіки ім. М.С. Полякова Нац. академ. наук України. - u 20121 09836; заявл. 14.08.12 ; опубл. 11.02.13, Бюл. № $3 .-3 \mathrm{c}$.

13. Пат. 71620 Україна, МПК В 07 В 1/46, 1/28. Вібраційний грохот [Текст] / В. Ф. Чумак, Ю. І. Сфремов, О. С. Уманець, О. С. Кофанов ; заявник і патентовласник ДП «Держ. проектно-конструктор. ін-т збагачув. устаткування «Діпромашвуглезбагачення». 2001129012 ; заявл. 25.12 .04 ; опубл. 15.12.04, Бюл. № 12. -3 с.

14. Пат. 103265 Україна, МПК В 07 В 1/28, 1/40, 1/46. Вібраційний грохот [Текст] / О. С. Уманець, В. І. Дробченко, В. О. Марин; заявник і патентовласник ДП «Держ. проектноконструктор. ін-т збагачув. устаткування «Дніпромашвуглезбагачення». - а 201206105 ; заявл. 21.05.12 ; опубл. 10.06.13, Бюл. № $18 .-4$ с.

15. Пат. 54580 Україна, МПК В 07 В 1/46, 1/28. Вібраційний грохот [Текст] / В. Ф. Чумак, Ю. І. Єфремов, О. С. Уманець, Г. П. Клочко, О. С. Кофанов ; заявник i патентовласник ДП «Держ. проектно-конструктор. ін-т збагачув. устаткування «Діпромашвуглезбагачення». - 2000084812 ; заявл. 14.08.2000 ; опубл. 17.03.03, Бюл. № 3. $3 \mathrm{c}$.

Рецензент д-р техн. наук, професор М.П. Ремарчук

Козар Леонід Михайлович канд. техн. наук, доцент кафедра будівельних, колійних та вантажнорозвантажувальних машин Українська державна академія залізничного транспорту. Tел.: 730-10-72. E-таіl: leokozar@gmail.com

Афанасов Георгій Михайлович канд. техн. наук, доиент кафедра будівельних, колійних та вантажнорозвантажувальних машин Українська державна академія залізничного транспорту. Tел.: 730-10-72. E-таіl: kafspprm2@rambler.ru

Харківський Олександр Сергійович, магістрант група МЗ-БКМ-13 Навчально-науковий інститут перепідготовки та підвищення кваліфікації кадрів Українська державна академія залізничного транспорту

Kozar Leonid Mykhailovych cand. science, associate professor, department of construction, track and handling machines, Ukraine State Academy of Railway Transport. Tel.: (057) 730-10-72. E-mail: leokozar@gmail.com

Afanasov Heorhii Mykhailovych cand. science, associate professor, department of construction, track and handling machines, Ukraine State Academy of Railway Transport. Tel.: (057) 730-10-72. E-mail: kafspprm2@rambler.ru

Kharkivskyi Oleksandr Serhiiovych student, group M3-БKM-13 Educational scientific institute of retraining and professional development personnel Ukraine State Academy of Railway Transport 